\title{
Shifting Fatherhood and Gender: Negotiating Power and Sexuality in Yorùbá
}

\author{
Oluwasola Daniels \\ Department of History, \\ University of California, Davis \\ oidaniels@ucdavis.edu
}

\begin{abstract}
Indeed, Yorùbá is one of the vastly researched ethnics in Africa, but all the sub-groups, like Àkókó, are not sufficiently known in scholarship. Thus, with specific focus on Àkókó, this paper discusses gender in pre-colonial marital practices. It argues that while some of these practices made fatherhood fluid and accrued uncommon agency to women, others framed women in taboo and sexuality. The central contribution of this paper is that as a study in gender, it brings the discourse within the framework of shifting fatherhood and sexuality in Yorùbá. The study is approached from historical perspective with the methodology of narration and critical analysis of data. This research uses inter-disciplinary approach like ethnography to have full grasp of the marital dynamisms. In all, non-homogenisation of history is crucial to understand hierarchies of power that shaped woman history and gender in Yorùbá.
\end{abstract}

Keywords: Gender; Agency; Marriage; Yoruba; Fatherhood

\section{Introduction}

Gender studies in Africa has received significant attention in recent times, especially over the originality of gender in African experience. Gender scholars in Africa like Oyeronke Oyewumi, Mary Modupe Kolawole, Desiree Lewis, Shireen Essof, Pinkie Mekgwe, Buchi Emecheta and others have espoused African feminist dialogues of different shades and paradigms, such that there are evidences of African women's connection and disconnection to 
gender. ${ }^{1}$ For instance, there is the orthodox gender school, which emphasises gender in African pre-colonial experiences. Here, it is affirmed that gender was an integral part of African history, demonstrated in its inheritance and widowhood cultures among others. On the other hand, another gender school, sees no gender in pre-colonial African history, but in African colonial history. Colonialism is seen as a disruption in Africa history. This is evident in British Victorian values, which emphasised domesticity and dependence of women on their husbands. ${ }^{2}$ Hence, attempt is geared towards decolonising and dispelling such hegemonic structures. In all, while the former school connects gender with pre-colonialism, the latter disrupts it. Such fluidities of African feminisms reflect epistemology that connects and disconnects gender.

These fluidities have also shaped debates on African feminism in contemporary times, such that responses in literature have both connected and disrupted the gender schools. Consequently, boundaries and dialogues created by fluidities are multi-dimensional and inexhaustible. For instance, one of the submissions of the non-orthodox school in Yorùbá is the absence of gender. Similarly, this research advances this submission by discussing non-gender

1 Oyeronke Oyewumi, What Gender is Motherhood? Changing Yoruba Ideals of Power, Procreation and Identity in the Age of Modernity, (New York: Palgrave Macmillan, 2016).

Oyeronke Oyewumi, "De-Confounding Gender: Feminist Theorizing and Western Culture, a Comment on Hawkesworth's Confounding Gender", Signs 23(4) (1998) https:// www.jstor.org/stable/3175203

Oyeronke Oyewumi, The Invention of Women: Making an African Sense of Western Gender Discourses, (Minnesota: University of Minnesota, 2010).

Mary Modupe Kolawole, Transcending Incongruities: Rethinking Feminisms and the Dynamics of Identity in Africa Agenda: Empowering Women for Gender Equity, No. 54, (Taylor \& Francis, Ltd., 2002) URL: http://www.jstor.org/stable/4548076 (Accessed: 0303-2017) 92-98.

Desiree Lewis, “African Feminisms”, And Agenda: Empowering Women for Gender Equity, No. 50, (Taylor \& Francis, Ltd, 2001) URL: http://www.jstor.org/stable/4066401 Accessed: 03-03-2017.

Shireen Essof, African feminisms: Histories, Applications and Prospects, Agenda (2001) 16:50, 4-10 http://dx.doi.org/10.1080/10130950.2001.9676003 124-127 (Accessed: 03-04-2018)

Pinkie Mekgwe, 'Theorizing African Feminism(s): The 'Colonial' Question' Quest: An African Journal of Philosophy / Revue Africaine de Philosophie XX, 2008, 11-22.

Buchi Emecheta, The Joys of Motherhood (Oxford: Heinemann Educational Publishers, 1994)

2 Oluwasola Ibitayo Daniels, "The Dynamics of British Colonial Culture on Nigerian Women, 1900- 1960: North-Eastern Yoruba Example”, Humanities and Social Sciences Review, vol.4 no.1 (2015) www.universitypublications.net/hssr/0401/html/DE4C247.xml, Rhode Island, USA, 222; Susan Kent, Sex and Suffrage in Britain 1860-1914 (Princeton: Princeton University Press, 1990), 91. 
specificity of marriage in Àkókó, a Yorùbá sub-group, during pre-colonial period. For example, while man could marry as many wives as he wanted, woman not only had the ability to freely divorce her husband and remarry, but the ability to negotiate fatherhood of her offspring.

On the other hand, the research also connects to the orthodox school in its study of gender in marital cultures of some Àkókó communities, like Ìsùà and Sósan Àkókó. Adultery was gender-specific. Woman was punished for adultery. In fact, it was a capital offence that involved death penalty for the woman. In sum, these two dimensions demonstrates Àkókó as hotbed of fluidities, which allows for seamless study of gender connections and disruptions. In a way, Àkókó's dynamism offers trajectories to study and globalise the concept of gender in Yorùbá and Africa.

One of the theories of studying African feminism is Historical Feminism. Oyeronke Oyewumi is one of the proponents of this theory. Yorùbá women were not victims of gender until it was imported by British colonial rulers. She argues that gender is a colonial construct that has transformed to sexism even among academics. ${ }^{3}$ Her work fits into the unorthodox gender school. In fact, her work avers that instead of debating African culture as prejudicial towards the female sex, scholars should focus on the history of the two sexes' roles. Hence, by using historical feminism theory, scholars must do research from the ground up and not just import assumptions. ${ }^{4}$ The emphasis on thorough research and non-homogenisation of Yorùbá culture punch the borderless value of the theory to historical research. A gender theory that celebrates heterogeneity in Yorùbá is apt for understanding gender in marital practices of a fluid Yorùbá subgroup, Àkókó, thus, it provides relevant framework for this study.

The paper answers the following research questions: How was elopement marriage practiced in Àkókó? Why was fatherhood fluid in Àkókó? Why or how were married women allowed to freely divorce and elope with another man, in an ethnic, divorce was touted difficult? How did fathers adjust to transfer of their offspring to another man? In what ways did this gender agency survive in an ethnic it was prohibited? Was this marriage universalised in all Àkókó communities? How can this marriage be compared with other marriages and marital practices in Àkókó? How can these fundamental

3 Oyeronke Oyewumi, "Decolonizing the Intellectual and the Quotidian: Yorùbá Scholars(hip) and Male Dominance", Gender Epistemologies in Africa Gendering Traditions, Spaces, Social Institutions, and Identities, Oyeronke Oyewumi (ed), (New York: Palgrave Macmillan, 2011), 9-35

4 Oyeronke Oyewumi, "Decolonizing the Intellectual and the Quotidian: Yorùbá Scholars (hip) and Male Dominance", 9-35. 
nuances complicate as well as contribute to the ongoing debates about gender and sexuality in Yorùbá and Africa?

Two themes, shifting fatherhood and sexuality taboo, are central to this paper. Literature used, are also woven around these themes. The works of Ayodeji Olukoju, S. K. Ogidan, Samuel Johnson, Olubayo Lawore, Gregory L. Forth, Clementine van Eck, Oyewumi, Rowland Abiodun, Moyo Okediji, Sigmund Freud and F. O'Doherty are important to these themes. ${ }^{5}$ The major arguments are: firstly, elopement marriage and shifting fatherhood and its legality or illegality. Secondly, gendered marital and sexual taboos and its comparability with elopement marriage. Forth and Eck provide basic understanding of elopement marriage in Turkey and Indonesia. It is celebrated marriage in these places. Indeed, Asia is culturally different from Africa, but the context of elopement marriage is comparable. For instance, provided some conditions were met, bride's parent approved of elopement marriage in Turkey and Indonesia. ${ }^{6}$

Lawore provides a general overview of different marriages in Yorùbá. Elopement marriage was an unconventional marriage which attracted ridicule to the couple and their families. ${ }^{7}$ Regarding this marriage as unconventional in Yorùbá is homogenisation of cultural practices, which is inappropriate in the context of Yorùbá cultural diversity. This marriage attracted no ridicule in many parts of Àkókó. Another homogenisation is observed in Johnson's work, where he avers that nobody marries divorced wife of a living man. Again, this runs afoul of Àkókó identity. In Ọ̀ kà Àkókó, wives divorced their husbands and remarried, by eloping with another man, to start a new family. The nuances left by this homogenisation are studied by this research. The works of Oyewumi, Rowland and Okediji are not on elopement, but on motherhood power in Yorùbáland. These works are necessary to understand the place of mothers in the society. While motherhood reserved power for women over

5 Olukoju Ayodeji, 'Oral Traditions and the Political History of Oka Akoko', History in Africa 20 (1993): 251 doi:10.2307/3171974; S.K. Ogidan, Isua Past and Present (Lagos: Datanomic Publication, 2013): Samuel Johnson, The History of the Yorubas (Lagos: CSS Limited, 2001); Olubayo Lawore, Cultural Ethos of the Yoruba (Ibadan: Kembim Press, 2004); Gregory L. Forth, Rindi: An Ethnographic Study of a Traditional Domain in Eastern Sumba, (Leiden: Brill,1981); Clementine van Eck, Purified by Blood: Honour Killings amongst Turks in the Netherlands, 105 (Amsterdam: Amsterdam University Press, 2003): https://www.jstor.org/stable/j.ctt46mx61.8, Oyewumi, Rowland Abiodun, Moyo Okediji, Sigmund Freud and F. O'Doherty

6 Clementine van Eck, Purified by Blood: Honour Killings amongst Turks in the Netherlands, 105 (Amsterdam: Amsterdam University Press, 2003): https://www.jstor. org/stable/j.ctt46mx61.8 ; Gregory L. Forth, Rindi: An Ethnographic Study of a Traditional Domain in Eastern Sumba, (Leiden: Brill,1981), 388.

7 Olubayo Lawore, Cultural Ethos of the Yoruba, 5. 
their offspring in general Yorùbá, it accrued power to negotiate fatherhood in Ộkà Àkókó. Thus, these works provide understanding that de-exorcises Àkókó peculiarity.

On the second theme of marriage and taboo, Freud in his study of ancient cultures argues that taboo is artificial and only exists because human allows for it, especially in their religions. ${ }^{8}$ F. O'Doherty corroborates this that fear of the unknown is an enabling factor for taboo, particularly fear of reprisal. ${ }^{9}$ Indeed, these are western authors, without total grasp of all Yorùbá practices, but, taboo was not devoid of human invention in pre-colonial Àkókó. The local peculiarity is thus, discussed in marital practices. Ogidan provides information on the history and human agency in marital taboo, known as Osi, in İsùà. The paper proceeds by engaging elopement marriage and gender.

\section{Shi (Elopement) Marriage and Shifting Fatherhood}

Elopement is not novel in marital discourse. It is generally used to refer to marriage carried out in secret, or couple living together without formal marriage. Scholars have debated and continue to debate the concept of elopement, especially over cultural legality or otherwise. Eck in a study on marriage and elopement amongst Turks discusses various reasons for elopement and conditions for its acceptability, even by parents of the bride. Among the reasons Eck enumerated were: rejecting arranged marriage, avoiding heavy financial cost of wedding by parents and desire to marry rich parent's child. ${ }^{10}$ Bride's parent approval for elopement is a form of recognition of this marriage.

In G. L. Forth's research on marriage in Rindi, Eastern Sumba region of Indonesia, elopement is called "paluhu ngandi or palai ngandi". ${ }^{11}$ It was not an unconventional way of marrying in the community. The groom's father could be privy to intending elopement or not. Following elopement, the groom "leaves behind two metal pendants with chains on the bride's sleeping mat, and a horse tied up outside. Traditionally, he would also leave a replica of the distinctive ear markings of horses belonging to his clan, as a clue to his identity". ${ }^{12}$ The items left behind would be used by the bride's family to initiate the

8 Sigmund Freud cited in O’Doherty, E. F. “Taboo, Ritual and Religion”, Studies: An Irish Quarterly Review 49, No. 194 (1960): 131. http://www.jstor.org/stable/30099141

9 O'Doherty, E. F. “Taboo, Ritual and Religion”, Studies: An Irish Quarterly Review 49, No. 194 (1960): 131.

10 Clementine van Eck, Purified by Blood: Honour Killings amongst Turks in the Netherlands, 105 (Amsterdam: Amsterdam University Press, 2003): https://www.jstor. org/stable/j.ctt46mx61.8.

11 Gregory L. Forth, Rindi: An Ethnographic Study of a Traditional Domain in Eastern Sumba, (Leiden: Brill,1981), 388.

12 Pennington Robert Connie et. Al, 'Leave the Running Shoes at Home: Addressing Elopement in the Classroom', Beyond Behavior 21, No. 3 (2012), 3. 
process of collecting bride-wealth and other required items from the groom's family. Also, the bride-wealth is subject to negotiation. The provision of the required items and its acceptance by the bride's family completes the process of contracting marriage. Here, elopement is culturally acceptable to Rindi people as a type of marriage.

In Yorùbá culture, Lawore calls elopement marriage "coup marriage". Generally, in Yorùbá culture, coup marriage was variously practised. While the consent of the bride is sought in some climes, the bride's consent was not required in others, rather, it was done with the consent of her parents. However, bride's consent was not sort in cases where she was getting too reluctant for marriage. ${ }^{13}$

In sum, elopement is partly tolerated in some cultures like Turkish and fully recognized in Rindi. In Nigeria, it was tolerated in Izon culture, and variously practised in Yorùbá communities. A convergence lies in these elopement stories: the consent of bride-to-be was sought prior to elopement, except in the case of bride's reluctance for marriage. Elopement marriage as a legitimate marriage was and is variously perceived in cultures across the globe. In eastern Yorùbá, where Àkókó is located, elopement marriage was also variously accommodated.

It was generally a marriage that involved man and woman elopers. It was called Shi marriage. Etymologically, the word "Shi" in Yorùbá literarily means "remove". In marital terms, the word translates to removing of woman without some marital rites like Idana (engagement rites) from her home to become wife to a man. Although, the marriage had different versions, the practice was commonplace throughout Àkókó. While Lawore calls it "an unconventional type of marriage" in Yorùbáland, ${ }^{14}$ at Ò̀ kà, this marriage was conventional. Homogenisation of marriage compromises identity and heritage.

In Shi marriage, the parents of the woman would have repeatedly received the fiancé as guest. Generally, the parents would not be oblivious of the man's identity. ${ }^{15}$ Also, he would have rendered agricultural services for his fiancée's parents. Another condition emphasised in this marriage is that the bride-to-be must approve of the relationship. During the Shi, the man in agreement with his fiancée secretly eloped to another quarter and the man announced the arrival of the new wife with a gunshot to the air. ${ }^{16}$ However, in Rindi's elopement discussed above, gunshot was not involved, rather, the groom left behind

13 Olubayo Lawore, Cultural Ethos of the Yoruba (Ibadan: Kembim Press, 2004) 5.

14 Olubayo Lawore, Cultural Ethos of the Yoruba, 5.

15 Interview with Joseph Alagbede, 65 years, Imole Deity Priest, No. 10 Irepodun, Oka Odo Quarters, Oka Akoko. 25th November, 2018.

16 Interview with Titi Haruna. 
two metal pendants with chains on the bride's sleeping mat. He would also tie a horse outside bride's house. In both cultures, something was used to signify elopement.

A middle aged respondent attests to this, that in the late nineteenth century, her great-grandmother eloped with her fiancé during an Ọ̀ kà market day. She further notes that the woman declined to marry her father's friend whom she felt was too acquainted with the family and her father's age mate, hence she chose to elope with her lover in order to reject her father's choice. ${ }^{17}$ The gunshot represented the final process of marrying a woman in Shi marriage of Ọ kà. The only caveat that must be respected by the union was the return of first daughter for Odeesan. ${ }^{18}$ This respondent also noted her maternal grandfather's insistence that as a first daughter, she must marry her male cousin:

My grandfather maintained I was his Odeesan, and insisted I must marry my male cousin, who is a medical doctor abroad. But we both refused since we felt we were too educated to continue that practice. He (grandfather) respected our decision because it was mutual rejection. ${ }^{19}$

The rejection noted above is not unconnected to modernisation which accounts for gradual extinction of the practice. Shi marriage was no less recognised than other marriages, where idana (engagement) took place. Other responsibilities a prospective husband performed for the in-laws during occasions and in farms was also observed by the man. ${ }^{20}$ The confidence and openness with which the people narrate and corroborate this practice, even in the present age, demonstrates that it could not have been a dishonourable practice in its heydays.

Meanwhile, there was another variant of this marriage. Married women could divorce their husbands and remarry, through the Shi marriage. In cases where a woman who had given birth to two or more children became dissatisfied with her husband, she could resolve to Shi marriage, by eloping with another man to a different quarter. She could even elope with her children and commence a new marriage. ${ }^{21}$

Ayodeji Olukoju, a renowned professor of African history and native of Iroho quarter, Ộkà À kókó, attests to subsistence of the indigenous practice in

17 Interview with Mrs Ogunode Usman 53 years, Teacher, African Church Grammar School, Oka, 10th December, 2018.

18 Odeesan was another marriage, which involved the union of first daughter to a member of her maternal family. Regardless of the kind of marriage of parents, the first daughter must be released for this marital tradition.

19 Interview with Mrs Ogunode Usman

20 Interview with Pa Gabriel Ajongbolo.

21 Interview with Titi Haruna. 
colonial period: “This happened to my grandfather's first wife, Adesoro, who remarried an Ikese man, around 1922/24. My great grandfather, Arije Olukoju, went to Ikese Quarter, to retrieve his infant grandson, whom he brought home under the fold of his agbádá (wide sleeve and loose-fitting robe). The grandson's name was Joseph Babalola Olukoju!"22 This is a practical example of how fathers adjusted to transfer of offspring to another man. It is also evident of mother's power to determine fatherhood of her offspring. Negotiating fatherhood may be unpopular culture in Yorùbá, but, the place of mother in offspring existence is not insignificant.

Yorùbá scholarship is awash with studies on the place of motherhood. Oyewumi in her publication on "Motherhood" in Yorùbá, used the term "matripotency" to explain the socio-spiritual and physical powers of mother on her children. ${ }^{23}$ She notes: "it was Olodumare (the Supreme Being) who gave "àwọn ìyá" (plural of İyá) power and authority over all their children humanity", ${ }^{24}$ (İyá here means mother). Rowland Abiodun stresses it further:

In the preparation of very powerful Yorùbá medicines, the one for curing mental sickness in particular, the patient's mother's breasts are washed into a concoction which is drunk by the patient. Also, if a man experiences a series of inexplicable disasters in his occupation or private life, he is usually advised to perform a ritual suckling of his mother's breasts to avert a repetition of these undesirable events. This is a means of purifying the source and essence of one's being. It is also believed that through this ritual suckling, a person is once more protected by a mother's powerful influence. ${ }^{25}$

In Yorùbá Art, Moyo Okediji echoes the relevance of motherhood. ${ }^{26}$ However, general Yorùbá epistemology on motherhood may not be succinct to explain Ò̀kà's peculiarity, but, it demonstrates that mothers have always had inalienable power over their children. History of Ộkà kingship may be helpful to probe further. An oral tradition of the town's kingship is traced to motherhood. Olukoju states that a king who had no male heir transferred his

22 Interview with Ayodeji Olukoju, 62 years, Professor of History, Department of History and Strategic Studies, University of Lagos, Lagos State, 23rd November 2019.

23 Oyeronke Oyewumi, What Gender is Motherhood: Changing Yoruba Ideals of Power, Procreation and Identity in the Age of Modernity, 58.

24 Oyeronke Oyewumi, What Gender is Motherhood: Changing Yoruba Ideals of Power, Procreation and Identity in the Age of Modernity, 65.

25 Rowland Abiodun, 'Woman in Yoruba Religious Images', 11.

26 Moyo Okediji, 'The Naked Truth: Nude Figures in Yoruba Art', Journal of Black Studies, Vol. 22, No. 1, African Aesthetics in Nigeria and the Diaspora (Sep., 1991), (Sage Publications, Inc.) https://www.jstor.org/stable/2784495 (Accessed: 22-11-2019) 31. 
kingship through his daughter to grandson known as Atikalaraewa. This was made through the following insignia of office: grandfather's hair, cap, wrist and neck beads. ${ }^{27}$ Till date, Asin kingship is traced from the mother's ancestry. Ọ̀ kà had reasons to celebrate motherhood: the paternal lineage of Atikalaraewa did not earn him kingship, but his maternal ancestry did. He became renowned through the kingship his mother's family negotiated for him. "Negotiation" of value or existence through maternal lineage had been part of Ọ kà's history. There may be more reasons for this negotiating power, but, this shows that motherhood had been prioritised in the community's history.

Upon further investigation on whether Shi resulted in any form of ridicule, it was widely claimed not to be ridiculous at all. ${ }^{28}$ Besides, it was common in virtually all families, hence, the mutuality did not give room for any form of mockery. In this second version of Shi, firing of gunshot into the sky was also required in announcing and sealing marriage in the husband's quarter. In Rindi and Turkish cultures, this version was not obtainable, especially, the aspect of a woman leaving a marriage with her offspring to another marriage. This is particularly a unique Ọ̀ kà marital practice. Hence, allowing wife to migrate to another marriage with children from previous marriage could be regarded as gender agency used for negotiating fatherhood and sexuality.

Meanwhile, firing of gun strongly indicates that $S h i$ was probably a nineteenth century invention. Historical accounts have shown that Àkókóland including Ọ̀ kà, did not have access to guns until the nineteenth century. According to Olukoju for instance, flintlocks, which was the first form of gun to be imported to Àkókóland, did not appear until the middle of the nineteenth century. ${ }^{29}$ His assumption agrees with the earlier position of Ajayi and Akintoye that Àkókó got its first share of firearms from Benin in the $1850 \mathrm{~s} .{ }^{30} \mathrm{Al}-$ though, this may mean Shi could be a nineteenth development, it is not also unlikely this was the century modification or improvement of the marriage. Hence, while the exact date of Shi cannot be totally ascertained, the history of an aspect of Shi can be established.

Another submission can be drawn in the two versions: man and woman could decide who they wanted to marry. Also, not only males could marry

27 Olukoju Ayodeji, 'Oral Traditions and the Political History of Oka Akoko', History in Africa 20 (1993): 251 doi:10.2307/3171974

28 All Oka respondents affirm this position.

29 Ayodeji Olukoju, 'The Siege of Oka, c.a 1878-84', Falola T. and Law R. (eds), Warfare and Diplomacy in Pre-colonial Nigeria: Essay in Honour of Robert Smith, (Madison: University of Wisconsin, 2003), 104.

30 J. F. A. Ajayi and S. A. Akintoye, Yoruba in the Nineteenth Century, Obaro Ikime (ed), Groundwork of Nigerian History (Ibadan: Historical Society of Nigeria, 1980), 295. 
more than one woman (polygyny), woman could also marry more than one man, though she must do this at different times.

Also, societal approval of elopement in the two Shi variants makes it different from the general betrothal culture across Yorùbáland. In sum, freedom to marry a man or woman of one's choice further makes marriage system unique in Ộkà. Indeed, Àkókó is a Yorùbá sub-group and thus part of Yorùbá patriarchal world-view, but marital practises were not consistent with patriarchal ethos. The admonition of historical feminism that scholars must do research from the ground up, is empirically right. It shows that micro history is rewarding, in its encompassing coverage, which grants audibility to unsung history. All these also show that non-homogenisation of history is crucial to uncover encompassing gender history.

This marriage was also obtainable in many Àkókó communities like Supare, Akungba, Irun, Ogbagi, Ese, Ikare and others. However, some distinctions abound. Unlike Ọkà, Shi was not an honourable marriage in Supare and Irun. Anyone who engaged in the practice must return to perform Idana ritual to bride's family. In Irun, any female who engaged in such was regarded as "sabokolo", literarily meaning "eloped with husband". ${ }^{31}$ However, if such a man demonstrated any act of responsibility to the father and mother of the bride regularly, like providing labour on the father's farm, provision of food items (like yam, palm-oil, bush-meat, kola-nut) to the mother and demonstration of goodwill during family occasions like giving palm-wine to the parents, the coup history could be forgiven.

Apart from this, the sábọk kolo bride and husband could atone for the act by coming to the bride's family with the husband's relatives to supplicate with kola-nuts and palm-wine. ${ }^{32}$ Here, the "coup" concept of Olubayo Lawore is appropriate, especially the unconventional label. Societal approval was not given for this kind of marriage, unlike Ọ̀kà version where ridicule was absent; derision was present in this variant. Also, like Rindi's elopement culture where collection of bride wealth legalised the marriage, collection of bride wealth and rendering of agricultural services to bride's parent also legalised this Shi. Accepting shared responsibilities from wife's family during ceremonies also toned down illegality in the marriage. While some responsibilities were required of the husband during future ceremonies of bride's family in these places, Ọ̀kà Shi husband also performed required services and responsibilities expected of husband, during ceremony from his wife's family. In all variants of $S h i$, the two sexes could choose their spouses which made all

31 Interview with Chief Aina Owolabi, the Bobatolu of Irun, 120c years. No 10. Okeubo, Irun Akoko. 11th October 2018.

32 Interview with Dr Stephen Aroge, 68 years. Pensioner and indigene of Irun Akoko. No. 7, road 2, Oba Ile Housing Estate. 7th December, 2018. 
Shi marriages distinctive to gender culture of independence and thus different from betrothal. The essence of this section is to show that the marriage was variously perceived. The fact that it was without derision in Ò̀ kà, did not globalise same throughout Àkókó. This difference is not far-fetched from the cultural fluidity of the subgroup.

\section{Marital Taboo, Sexuality and Ancestral Worship}

Taboo is central to this section, hence, the concept is briefly contextualised to provide understanding. As a cultural word, taboo is a global phenomenon engaged in scholarship across many disciplines. It is loosely used to identify persons and groups in terms of what they do or not do. Sigmund Freud is regarded as one of the earliest and leading authorities on taboo concept. In his famous publication, Totem and Taboo, culture and collective psyche are engaged as trajectories to thought framing that build up as totem and taboo. In his studies of ancient cultures, he examines taboo as natural phenomenon that can be explained psychologically. ${ }^{33}$ Human was not born with respect for taboo, it is learned and can be unlearned. To Freud, religion is fundamental to composition of taboo. Religion imbues anxiety in people, which necessitates ritualistic responses known as taboo. Taboo is grounded in belief system and religious structures.

F. O'Doherty in a study on Taboo, Ritual and Religion, analyses taboo as a universal term that emphasises 'prohibition' through "horror, fear, self-loathing, dread of the unknown, revulsion, desire for punishment and perhaps other factors". ${ }^{34}$ Taboo enforcement here is related to Freud on the subject-matter as neurotic disposition. Reprisal effect learned by humans predisposes them to taboo prevention. Michael Lambek sees taboo as "the inverse of exchange in the sense that it can enact the rejection of a social relationship, it does provide a means of affinity for those who agree to hold a taboo in common" 35 . Essentially, taboo ignites a sense of belonging among a people. Lambek goes further that it is a basis of hierarchical relationships among a group of people. One of the hierarchies of relationships, in the society, is marriage. Taboo is woven around the institution of marriage. In pre-colonial Yorùbá, from pre-wedding to wedding and post wedding arrangements, marriage was surrounded by taboo. In Àkókó, some taboos were gender-specific in marriage.

33 Sigmund Freud cited in O'Doherty, E. F. “Taboo, Ritual and Religion”, Studies: An Irish Quarterly Review 49, No. 194 (1960): 131. http://www.jstor.org/stable/30099141

34 O’Doherty, E. F. “Taboo, Ritual and Religion”, Studies: An Irish Quarterly Review 49, No. 194 (1960): 131.

35 Michael Lambek, “Taboo as Cultural Practice Among Malagasy Speakers”. Man, New Series, 27, no. 2 (1992): 249. doi:10.2307/2804053. 
In İsùà and Sósan Àkókó, taboo was part of the belief system, especially in marriage. In İsùà, pouring of libation on the floor at the house of a bride's father for ritual prayers was the marital sealing that bound woman to man as husband and wife. ${ }^{36}$ Other rituals like prayers from the paternal and maternal families would also follow. During the marital ritual, the groom's family would announce the taboos in the family and quarter. One of the marital taboos was that adultery or any amorous relationship between a married woman and man who is not her husband was forbidden. ${ }^{37}$

Furthermore, sex before marriage was a taboo. A girl must not engage in any affectionate relationship with her husband or fiancé, else, Ugar, the punishing god, would bring heavy penalty (mysterious sickness leading to death) on the perpetrators (man and woman) or the woman only. Even when the god could still be appeased, appeasement did not always mean forgiveness; in fact, the culprit would still have a taste of penalty after appeasement. ${ }^{38}$ Therefore, preservation of virginity was viewed as a matter of life and death.

Even after the wedding ceremony, consummation of marriage must not be observed until five days into the marriage. In other words, sex immediately after wedding was a taboo. Generally, any cordiality between married woman and another man was seriously prohibited. For example, the king of İsùà, Olísùà, notes that man must not sit on any spot a married woman gets up from..$^{39}$ Even crossing stretched leg of seated married woman by a man (who is not her husband) must be atoned. Communication between married woman and man must be at a distance. ${ }^{40} \mathrm{~A}$ critical study of these taboos presupposes some submissions: closeness of man and married woman was abhorred, due to some reasons. Sexuality could be at the centre of such feuds. This is attested to by respondents. ${ }^{41}$ Taboo was built into unwanted social relationship to prevent sexual crime. As Michael Lambek notes, taboo endorses rejection of social relationship. Here, communication or contact between married persons of opposite sex was assumed to predispose them to abominable acts, hence enactment of taboo to prevent it.

36 Interview with Dr Kikelomo Victoria Olugbemi, 63 years, Senior lecturer, Department of History and International Studies, Adekunle Ajasin University, Akungba Akoko, Ondo State. 4th December 2018.

37 Interview with Ojo Akeredolu, 60 years, head of deity priests, E/31 Iminagbede Quarters, Isua Akoko, 27th November 2018.

38 S.K. Ogidan, Isua Past and Present (Lagos: Datanomic Publication, 2013) 60.

39 Interview with Akinyele Adesunloye Oyolola III, Olisua (king) of Isua-Akoko, king's palace Isua, 10th November, 2016.

40 Interview with Ojo Akeredolu.

41 Interview with Akinyele Adesunloye Oyolola; Interview with Emmanuel Anjorin, 55 years, Civil Servant, Rufus Giwa Polytechnic, Owo, 10th April 2015 and Interview with Ojo Akeredolu. 
However, it needs be stated, adultery known as $O s i$ was gender specific. Sexual relationship between a married woman and a man different from her husband was regarded as adultery in İsùa context. On the other hand, sexual relationship between married man and another unmarried woman was not regarded as same. Controlling female sexuality was at the centre of Osi. In other words, adultery was feminised in the practice, ignoring the involvement of man in the 'sexual sin'. The man who engaged in the act with her was not penalised, neither was the husband involved in extra-marital affair, regarded as an adulterer. These emphasise male exoneration in criminalising extra-marital sex. Here, gender stereotype emphasises artificiality of taboo and the definition of gender as socio-cultural term, not natural or innate. Thus, gender is rewarding here as a category of analysis because it offers a way to decode meaning, especially in sexualising extra-marital affair as feminine. It shows that gender was a way of organising Ìsùà marital system and re-echoes management of female sexuality by the society.

Meanwhile, non-programmatic nature of gender makes another category of analysis discernible in the Osi culture. Penalty that encapsulated husband and wife could be gleaned from this taboo. Although, adultery was abominable for only women, husband could also be punished. He was liable to this punishment, if he had sexual relationship with the woman after the act. In some cases, offspring (female and male) of the woman could die first if she tarried in confessing the crime. ${ }^{42}$ Therefore, while a man could marry many wives as was the case in polygamous society, Osi penalty was shared by the family. Perpetration of $O s i$ was specific to women, but penalty was not entirely gender-specific, as it could also be visited on male children and husband. In fact, S. K Ogidan notes: "It is for the gods to choose who receives the punishment". 43

Specifically, penalty was multi-faceted: mysterious sickness till death such as mouth tearing or sores, shadow boxing, swelling of stomach and hallucination. ${ }^{44}$ Meanwhile, a repentant culprit could appease the god of Osi through its priest. Each quarter had an Osi priest dedicated to the worship and spiritual cleansing of culprits. For instance, Oyara quarter was managed by OkuOya clan. Items like big white cock, kola-nut, cowries and old coins must be presented. Instead of cock, some quarters requested goat. However, this did not guarantee total cleansing of the culprit as it could still be visited on the

42 Interview with Dr Kikelomo Victoria Olugbemi.

43 Ogidan, Isua Past and Present, 61.

44 Ibid, 60. 
offspring. ${ }^{45}$ It should be noted that appeasement worked if the woman confessed before punishments set in; otherwise, death would not be averted. ${ }^{46}$

Taboo was also woven around divorce. Unlike Ọ̀ kà, where wife could use Shi marriage to divorce, divorce was rare in İsùà. In extreme cases, where divorce could not be averted, the woman must engage in a traditional cleansing process prior to another relationship. Even death of husband was not enough to dissolve marital union, the same traditional cleansing must occur before remarrying. ${ }^{47}$

While İsùà taboo was greatly woven around sexuality, Sósan marital taboo was centred on ancestral worship. According to M. Fortes, ancestor worship is grounded in the belief that the dead lives and are able to influence the life of the living. Ancestors are believed to be capable of being both friendly and hostile to the living. ${ }^{48}$ Therefore, respect and fear are instilled into their worship. Norman Townsend in his study on 'Ancestor Worship and Social Structure' argues, "... implied in the term 'worship of the dead' is the idea of the active participation of the dead in mundane affairs" ${ }^{49}$ Belief in the existence of deceased ancestors and their involvement in human activities accords potency to ancestral worship. While some scholars regard ancestors as dead male and female, others like David Bogopa assign ancestral worship in South Africa to only males.

In Sósan Àkókó, the gender of the ancestors worshipped was not emphasised, but both genders were involved in the worship. However, it must be noted that Sósan ancestral worship is connected to its history. Sósan is one of the communities that claim Edo ancestry: ${ }^{50}$ this might explain ancestral worship similarities to the later. James Thayer Addison notes that ancestral worship was household supplication in Edo, “...every house has its shrine and its household worship... The ancestors are represented sometimes by long wooden starves carved with decorations, sometimes by heads of wood

45 Interview with Emmanuel Anjorin.

46 Interview with Dr Kikelomo Victoria Olugbemi.

47 Interview with Akinyele Adesunloye Oyolola.

48 M. Fortes as cited in David Bogopa, "Health and Ancestors: The Case of South Africa and Beyond", Indo-Pacific Journal of Phenomenology Vol10, May 2010, 1. http://10.2989/IPJP.2010.10.1.8.1080

49 Norman Townsend, "Ancestor Worship and Social Structure: a Review of Recent Analyses", A Master Thesis submitted to the Faculty of Graduate Studies in Partial Fulfilment of the Requirements for the Degree of Arts McMaster University, 1969. 23.

50 National Archive Ibadan (N.A.I.) Chief Secretary's Office (C.S.O) 26, 29667, vol. II, 'J.H. Beeley Intelligence Report on the Akoko Area of the Owo Division, Ondo Province', 1934, 138-140. 
or bronze." ${ }^{51}$ Similarly, in Sosan, apart from central ancestral shrines, there were household shrines for the veneration of ancestors and solemnization of marriage. Prior to fun-fare engagement ceremony, marriage would be first solemnized at the ancestral shrine known as Ighare. The shrine was a designated site present in every quarter as intercessory point between the people and the ancestors. Here, groom takes palm-wine to Ighare with elders from the quarter. The elders would pour the wine on the shrine and chant some prayers binding the man and woman. ${ }^{52}$ This act was marriage seal between the two, hence the woman must not engage in adultery, otherwise she would die. Unlike İsùà, where atonement with cock or goat could appease Osi god, there was no appeasement for breaking adultery taboo in Sósan. The discharging process common to İsùà for widows was also common to Sósan, with some modifications. In Sósan, either the widow wanted to remarry within the family or not, she must take a goat to the shrine after three months of mourning for release rituals. Only this could discharge the woman of the marital bond. Generally, discharge must occur to prevent premature death of the widow. ${ }^{53}$ On the other hand, such taboos did not exist for widowers.

However, unlike İsùà, where adultery penalty could be borne by husband and wife, in Sósan, only the woman faced the consequences. This could be gleaned from the history of adultery taboo in the two towns. In İsùà, oral tradition has it that at a time when İsùà was ravaged by insecurity, the warriors that went out to fight in defence of the community returned to find their wives impregnated by other men (out of rape or adultery). Hence, the warriors refused to go to war again. ${ }^{54}$ The continued security challenges made the king invite a diviner from Benin to find solution. The invited diviner instructed that two earthen pots containing livers and blood of two non-indigenes must be buried in the town to prevent any future occurrence. However, the diviner and his wife were later slaughtered and used instead: Ìsùà could not find any strangers at the time. This act was believed to have brought involvement of husband in extra-marital penalty of wife, as the killers of the diviner were men. ${ }^{55}$

51 James Thayer Addison, "Ancestor Worship in Africa", The Harvard Theological Review, Vol. 17, No. 2 April 1924, 153, http://www.jstor.org/stable/1507611 Accessed: $04 / 10 / 2010$.

52 Interview with Christopher Jide Ayeni, 65 years, Pensioner, no. 8 Upara quarters, Sosan Akoko. 12th December 2018

53 Interview with Jerome Coker, 68 years, Pensioner, no. D/2 Adoro quarters, Sosan. 12th December,2018.

54 Interview with Ojo Akeredolu. Interview with Dr Kikelomo Victoria Olugbemi.

55 Interview with Ojo Akeredolu. 
On the other hand, in Sósan, prevalence of adultery necessitated their taboo. Since the people operated Opon system, a form of gerontocracy, ancestors were consulted to adjudicate on any adultery case, hence, the marital rite at Ighare shrine. Consequently, the oldest in the family performed the rite at the ancestral shrine, which served to connect the living with ancestor. Developments leading to the commencement of these marital taboos underpin these gender differences. In spite of the fact that a man had the liberty of marrying many wives in İsùà, male and female were involved in the consequences of $O s i$ taboo in the town. However, the Ighare system penalised only females in Sosan.

It could appear that these cultures were differently fore-grounded and Ìsùà seemed more gender balanced than Sosan in the taboo penalty, they both had feminine underpinnings. Both accused married women of infidelity: taboo was framed around women sexuality. In other words, adultery was gender-specific. Married men who engaged in sex outside marriage were not guilty of adultery. Polygamy may be assumed as an explanation for man's right to sex, but polygamy is slightly different. It was marriage of man to more than one woman; marriage was required before sex to more than one woman. But, in this case, sexual relations without marriage was not penalised for man.

Gender has been identified as trajectory for organising social relations by scholars. Cecilia Ridgeway lends credence to this by suggesting that gender "is a primary cultural frame for coordinating behaviour and organizing social relations" ${ }^{56}$ In İsùà and Sosan contexts, gender taboo is used to regulate marriage and sexuality as categories of social relations. The idea of taboo as a means of identification is shown here: gendered taboo forms part of the two communities' identities: these taboos were unique to them, as it was not obtainable in other Àkókó villages. Thus, in the social categorisation of marriage, gender featured prominently as a primary frame.

\section{Comparison of Shi and Osi}

Marriage in Ọ̀kà, İsùà and Sosan are interesting, comparatively. While Ộkà and İsùà are not up to five kilometres apart, the Shi marriage was a deadly taboo in the later. Pouring of libation in both İsùà and Sosan as sealing of marriage is absent in Shi, rather, it was gunshot. Hence, to these two towns, such marriage only by firing gunshot into the sky was not binding. In fact, consummation taboo in the first five days of marriage in Ìsùa further makes Shi marriage abominable in the town. While a married woman had

56 Cecilia L. Ridgeway, 'Framed Before We Know It: How Gender Shapes Social Relations'. Gender and Society, Vol. 23, No. 2 April 2009, Sage Publications, Inc. http:// www.jstor.org/stable/20676769 (Accessed: 22-02-2018). 145. 
the liberty to elope with her children to marry another man, it was grievous taboo in İsùà and Sósan. It was more deadly in Sósan as it had no atonement. In both Ìsùà and Sósan, ritual rites must be performed for a woman to procure divorce. On the other hand, a woman was empowered to divorce and move to another marriage through Shi. She could also negotiate fatherhood of her offspring, because, moving to another marriage transferred fatherhood from her former husband to new husband. Therefore, fatherhood was fluid. This was an uncommon agency for woman, as it was not popular in Yorùbáland. Shi as a micro-history of Yorùbá further enriches the versatility of the ethnic. These striking heterogeneities could be gleaned from trio's histories.

Again, in all variants of $S h i$, the liberty of the two sexes to choose their spouses makes all elopement marriages unique to gender and different from betrothal culture. This research does not disregard betrothal marriage in Àkókó, but compliments the marriage system as an extension of cultural dynamism. In sum, elopement and marital taboo depict gender differently. While elopement accentuates freedom of male and female to marry at will, taboo curtailed the liberty of female to freely migrate from one marriage to another. However, penalty of $O s i$ taboo partly erases gender difference; offspring of the culprit partook in the consequences; continued sexual relationship with the husband extended punishment to the man. Thus, a form of gender paradox is warped in elopement culture.

Francine M Deutch in a study on gender concept, submits that factors, which create sexual stereotype against female are regarded as "doing gender", while "social interactions that reduce gender difference" could be summed as "undoing gender". ${ }^{57}$ In comparison, while İsùà taboo sexuality created gender hierarchy for male, thus doing gender, Ộkà reduced gender in its sexuality freedom for woman. In Deutch's proposition therefore, İsùà could be regarded as "doing gender", with ọ̀ kà "undoing gender". The experience of women in the two communities is indeed paradoxical. It reflects the submissions of the gender schools discussed earlier. Shifting fatherhood evince the non-orthodox school's emphasis on thorough research to unearth woman agency, thereby dispelling gender in pre-colonial period. The gender framing of adultery reflects the orthodox gender school, which emphasises gender in pre-colonial history. Thus, fluidity allows for seamless study of global themes.

This fluidity, is one of the reasons scholars emphasise artificiality of gender as socio-cultural construct and not natural. As Oyewumi notes, "Gender is first, and foremost, a cultural construct. As such, it is intelligible only in a

57 Francine M. Deutsch, 'Undoing Gender', Gender and Society, Vol. 21, No. 1 Feb., 2007, (Sage Publications, Inc.) https://www.jstor.org/stable/27640948 122. Accessed: 23-11-2019. 
cultural frame.... Thus any claims made on the basis of studies in one culture cannot necessarily hold true for other cultures and should not be universalized." ${ }^{, 5}$ Indeed, 'adultery' cannot be universalised in Àkókó: while İsùà feminised the act, Ộkà did not recognise in Osi. Again, this echoes the argument of Deutsch that there is no rigid way of doing 'gender', it is transient or fluid. ${ }^{59}$

All these peculiarities centred on elopement and taboos lend credence to the fact that gender is not programmatic, it is hugely defined by culture. Culture delimits the place of gender in categorisation of role and identity. However, the non-static feature of gender accounts for its continued relevance in scholarly debates. While this study revolves around culture, gender is the mechanism for interpreting the distinctive identity of groups.

\section{Conclusion}

Fluidity of Àkókó marital cultures makes the two gender schools apt in discussing gender connections and disruptions. Shi and sexuality taboo are rewarding trajectories for the schools. Shi shows that while man could marry as many wives as he wanted, woman not only had the ability to freely divorce her husband and remarry, but the ability to negotiate fatherhood of her children. Unlike the traditional involvement of parents in child's choice of spouse, Shi empowered male and female to choose their spouses. Shi was carried out by married women to make divorce a fait accompli. Leaving one marriage for another through Shi did not just serve as a form of divorce, it also signified the power of choice: male and female could choose who they wanted to marry. This complemented the traditional betrothal culture, in other words, modern practice of male and female choosing partner was obtainable in pre-colonial Ọ kà. In sum, Shi signified three submissions: fatherhood negotiation, power of choice and freedom to divorce.

Osi may not be totally gender-specific in appropriation of penalty, but, only woman was framed for adultery. Controlling married female sexuality was central to enactment of $O s i$ taboo, otherwise, unmarried male was not penalised for engaging in sexual relationship. In Sosan, ancestral-linked taboo was central to their marriage culture. The belief in active participation of the dead in the living's activities affects societal behaviours including marriage, such that survival depended on the verdict of the dead. Thus, ancestors were never dead but in transition to another sphere of elders. In the control of married

58 Oyeronke Oyewumi, 'De-Confounding Gender: Feminist Theorizing and Western Culture, a Comment on Hawkesworth's Confounding Gender', Signs, Vol. 23, No. 4 (Summer, 1998), (Chicago: The University of Chicago Press), https://www.jstor.org/stable/3175203 1050. Accessed: 23-11-2019.

59 Francine M. Deutsch, 'Undoing Gender', Gender and Society, Vol. 21, No. 1 Feb., 2007, 106-127. 
female's sexuality, gender was one of the terms of reference in advisory roles of the ancestors.

Gender shows the rewarding value of studying culture thoroughly. Homogenisation of cultures compromises identity and heritage. This brings to mind, the validity of some suppositions on Yorùbá marriage. For instance, Samuel Johnson, while noting that divorce was rare in Yorùbáland writes that "a woman divorced from her husband can never be married, or taken up legally by another man; hence the saying, a kì i sú opó alàyè (no one can inherit the relict of a living man)" ${ }^{60}$ The certainty shown in this excerpt shows that remarrying a divorced woman was not culturally acceptable in many parts of Yorùbá. However, this was far from reality in Ọ̀ kà. The fact that Ọ̀ kà did not conform to the general Yorùbá practice does not trivialise or phase out its distinctive culture. It demonstrates that the study of micro-history is expedient to understand Yorùbá cultural identities. All these cultural distinctions emphasise that homogenisation of cultures is not promising and Àkókó as home of cultural fluidity is a fact-checker for Yorùbá gender history. Indeed, Yorùbá is one of the heavily researched ethnics in Africa, final word about its pre-colonial cultures may not be known until encompassing research is carried out.

60 Samuel Johnson, The History of the Yorubas (Lagos: CSS Limited, 2001) 116. 
